\title{
Rational Design, Synthesis, In Vitro, and In Silico Studies of Dihydropyrimidinone Derivatives as $\beta$-Glucuronidase Inhibitors
}

\author{
Somaye Karimian (D), ${ }^{1}$ Yasaman Moghdani, ${ }^{1}$ Mahsima Khoshneviszadeh ${ }^{(D)}{ }^{2}$ \\ Somayeh Pirhadi, ${ }^{2}$ Aida Iraji $\mathbb{D}^{2,3}$ and Mehdi Khoshneviszadeh $\mathbb{D}^{1,2}$ \\ ${ }^{1}$ Department of Medicinal Chemistry, School of Pharmacy, Shiraz University of Medical Sciences, Shiraz, Iran \\ ${ }^{2}$ Medicinal and Natural Products Chemistry Research Center, Shiraz University of Medical Sciences, Shiraz, Iran \\ ${ }^{3}$ Central Research Laboratory, Shiraz University of Medical Sciences, Shiraz, Iran
}

Correspondence should be addressed to Aida Iraji; aida.iraji@gmail.com and Mehdi Khoshneviszadeh; m.khoshneviszadeh@ gmail.com

Received 5 November 2020; Revised 20 January 2021; Accepted 7 February 2021; Published 26 February 2021

Academic Editor: Honghong Wu

Copyright (c) 2021 Somaye Karimian et al. This is an open access article distributed under the Creative Commons Attribution License, which permits unrestricted use, distribution, and reproduction in any medium, provided the original work is properly cited.

\begin{abstract}
In the current study, a series of dihydropyrimidinone derivatives were rationally designed as $\beta$-glucuronidase inhibitors. These designed compounds were successfully synthesized and characterized through various spectroscopic techniques such as IR, ${ }^{1} \mathrm{H}$ $\mathrm{NMR},{ }^{13} \mathrm{C}-\mathrm{NMR}$, and EI-MS. A structure-activity relationship (SAR) of synthesized derivatives to inhibit $\beta$-glucuronidase was also established. In vitro biological evaluations revealed that $\mathbf{4 i}$ as the most potent compound in this series has an $\mathrm{IC}_{50}$ value of $31.52 \pm 2.54 \mu \mathrm{M}$ compared to the standard D-saccharic acid 1,4-lactone $\left(\mathrm{IC}_{50}=41.32 \pm 1.82 \mu \mathrm{M}\right)$. Also, molecular docking and dynamics studies of the most potent compound are performed to evaluate interactions between the active compound and binding site.
\end{abstract}

\section{Introduction}

$\beta$-glucuronidase belongs to the glycosidase family with $332 \mathrm{kDa}$ distributed in lysosomes of mammalian tissues and body fluids, while significantly reserved in the endoplasmic reticulum [1]. Human $\mathrm{x}$-ray crystallography of the protein structure reveals three distinct structural domains: (I) jelly roll motif also named lysosomal targeting motif with barrellike structure, (II) immunoglobulin constant domains, and (III) $\alpha / \beta$ or TIM barrel domain, which possesses the active site of the enzyme comprise of Glu451 as a proton donor, Glu540 known as a catalytic nucleophile, Tyr504 (uncertain catalytic role), and Asp207 (plausible role as Glu540) [2]. The biological function of $\beta$-glucuronidase is to cleave the glycosidic bond of glycans ( $\beta$-linked glucuronides), release glucuronic derivatives, and produced physiological responses. Besides, $\beta$-glucuronidase incorporates $\beta$-glucuronides into steroids and helps in the recirculation of vitamin $D$, estrogen, and thyroid hormone $[2,3]$. Deficiencies in $\beta$-glucuronidase result in a metabolic disease known as Sly syndrome or mucopolysaccharidosis type VII [4]. On the other hand, the overexpression of the enzyme is reported in some solid tumors, necrotic areas, and infected tissues $[5,6]$. $\beta$-glucuronidase is also found to be involved in the etiology of hepatic diseases [7], inflammatory joint diseases [8], colon cancer, liver cancer, and AIDS $[2,9]$. These reports suggest that the development of specific $\beta$-glucuronidase inhibitors has great pharmacological importance. Several molecules from natural origin including flavonoids [10], iminosugars [11], thiosulfinate [12], terpenoids, and steroids [13] have proven to be promising $\beta$-glucuronidase inhibitors. Also, some successful synthetic $\beta$-glucuronidase inhibitors such as imidazole [14], imidazolopyridine [15], benzimidazole [16], thiazole [17], 1,3,4-thiadiazole [18], and 1,3,4-oxadiazole derived scaffolds were also reported.

Dihydropyrimidinones are heterocyclic compounds synthesized by simple multi-component reactions such as the Biginelli reaction with a variety of methodologies 
$[19,20]$. Dihydropyrimidinones have been identified to possess a wide range of applications in pharmacology and medicinal chemistry including anticancer [21], antiinflammatory [22], antimicrobial [23], antidiabetic, and antioxidant agents [24]. This skeleton also showed a broad spectrum of biological activities including calcium channel antagonism/inhibition, Eg5 kinesin, and topoisomerase I inhibitor [25]. Considering $\beta$-glucuronidase inhibition, dihydropyrimidone and pyrimidine structures were first reported as a successful example in rational drug design against $\beta$-glucuronidase [26, 27]. Recently single point modification on pyrimidine resulted in designing thioxotetrahydropyrimidines which showed excellent inhibitory potency in vitro against $\beta$-glucuronidase with an $\mathrm{IC}_{50}$ value of $0.35 \mu \mathrm{M}$ for the most potent compound. According to their docking and MD research, conformational stability of this compound was seen within the enzyme active site through hydrogen bond interactions with Tyr205, Asp207, and Glu451 residues.

As a result, the dihydropyrimidinone structure was selected due to several reasons. (I) The dihydropyrimidinone structure was chosen due to the significant $\beta$-glucuronidase inhibitory potential reported in limited studies. (II) To the best of our understanding, limited data are available concerning SAR of dihydropyrimidinone structure against $\beta$-glucuronidase. (III) The unique power of multicomponent reactions to synthesize dihydropyrimidinone structure is recognized as an extremely valuable strategy to reduce time, cost, and energy.

In continuation of our ongoing research on heterocyclic compounds with bioactivity and pharmacological importance of $\beta$-glucuronidase inhibitors, herein, we report the design and synthesis of dihydropyrimidinone analogs to evaluate their $\beta$-glucuronidase inhibitory potentials.

\section{Materials and Methods}

2.1. General. Melting points of synthesized compounds were determined on a Kofler hot stage apparatus. ${ }^{1} \mathrm{H}$ and ${ }^{13} \mathrm{C}$ NMR spectra were determined on a Bruker $500 \mathrm{MHz}$ NMR. The letters s, d, t, q, and $\mathrm{m}$ are used to indicate singlet, doublet, triplet, quadruplet, and multiplet. Coupling constants $(J$ values) are quoted in hertz $(\mathrm{Hz})$. The mass spectrometric analysis was conducted by using ESI mode on the Agilent 7000-triple quad instrument at $70 \mathrm{eV}$ (Santa Clara, CA, USA). IR spectra were recorded on an FTIR-470 Shimadzu spectrophotometer.

\subsubsection{General Procedure for the Synthesis of Dihydropyr- imidinone Compounds $(\mathbf{4 a - i})$. Dihydropyrimidinone} analogs were synthesized by refluxing N,N-diethyl-3-oxobutanamide $(1,1 \mathrm{mmol})$, urea $(2,1.2 \mathrm{mmol})$, and different aldehyde $(3,1 \mathrm{mmol})$ in the presence of $\mathrm{FeCl}_{3} \cdot 6 \mathrm{H}_{2} \mathrm{O}(15 \%$ $\mathrm{mmol}, 0.0405 \mathrm{mg}$ ) in $20 \mathrm{~mL}$ acetonitrile for 24 hours. After completing the reaction (monitored by TLC, $n$-hexane/ethyl acetate, $3: 7 v / v)$, the reaction mixture was cooled to room temperature and the reaction mixture was diluted with water, poured into crushed ice, and allowed to stir for $1 \mathrm{~h}$ to obtain maximum precipitation. The precipitated product was filtered off and washed with cold water. All products were recrystallized from hot ethanol to give pure products.

(1) N, N-Diethyl-6-methyl-2-oxo-4-phenyl-1,2,3,4-tetrahydropyrimidine-5-carboxamide (4a, Figure S1). Cream solid; isolated yield: $58 \%$; M.P: $138-143^{\circ} \mathrm{C} ;{ }^{1} \mathrm{H}$ NMR $(500 \mathrm{MHz}$, DMSO- $\left.d_{6}\right) \delta$ ppm: $8.47(\mathrm{~s}, 1 \mathrm{H}), 7.35-7.29(\mathrm{~m}, 3 \mathrm{H}), 7.28-7.23$ (m, 1H), 7.19 (d, J=7.0 Hz, 2H), 5.02 (s, 1H), 3.03 (brs, 4H), 1.63 (s, 3H), 0.89 (s, 3H), 0.52 (s, 3H); ${ }^{13} \mathrm{C}$ NMR $(125 \mathrm{MHz}$, DMSO- $\left.d_{6}\right) \delta$ ppm: 167.81, 153.07, 144.43, 130.58, 128.90, 127.87, 126.70, 105.05, 60.21, 57.67, 16.11, 14.54; MS (EI), $m /$ $z(\%): 287\left(\mathrm{M}^{+}, 100\right), 215(52), 185(97), 172(46), 131(46)$, $72(67)$; IR (KBr) $v \max \left(\mathrm{cm}^{-1}\right): 3420,3245,3108,3062,2973$, 2931, 1676, 1610, 1544, 1455, 1349.

(2) N, N-Diethyl-6-methyl-4-(2-nitrophenyl)-2-oxo-1,2,3,4tetrahydropyrimidine-5-carboxamide (4b, Figure S2). Cream solid; isolated yield: $88 \%$; M.P: $248-252^{\circ} \mathrm{C}$; ${ }^{1} \mathrm{H}$ NMR $\left(500 \mathrm{MHz}, \mathrm{CDCl}_{3}\right) \delta \mathrm{ppm}: 8.50(\mathrm{~s}, 1 \mathrm{H}), 7.94(\mathrm{~d}, J=8 \mathrm{~Hz}, 1 \mathrm{H})$, $7.82(\mathrm{~d}, J=8 \mathrm{~Hz}, 1 \mathrm{H}), 7.68(\mathrm{t}, J=8 \mathrm{~Hz}, 1 \mathrm{H}), 7.46(\mathrm{t}, J=8 \mathrm{~Hz}$, $1 \mathrm{H}), 6.03(\mathrm{~s}, 1 \mathrm{H}), 5.66(\mathrm{~s}, 1 \mathrm{H}), 3.37(\mathrm{~s}, 4 \mathrm{H}), 1.94(\mathrm{~s}, 3 \mathrm{H}), 1.06$ $(\mathrm{t}, J=7.2 \mathrm{~Hz}, 6 \mathrm{H}) ;{ }^{13} \mathrm{C} \mathrm{NMR}\left(125 \mathrm{MHz}, \mathrm{CDCl}_{3}\right) \delta \mathrm{ppm}$ : $165.98,152.84,147.67,146.94,134.74,133.08,129.70,128.19$, $123.87,102.54,51.72,41.70,15.32,12.78$; MS (EI), $m / z(\%)$ : 331 $\left(\mathrm{M}^{+}, 2\right), 213(18), 185(36), 100(100), 72(47)$; IR (KBr) $v \max \left(\mathrm{cm}^{-1}\right): 3236,3111,2976,2934,1704,1608,1528$, 1477, 1458, 1379, 1335.

(3) N,N-Diethyl-6-methyl-4-(3-nitrophenyl)-2-oxo-1,2,3,4tetrahydropyrimidine-5-carboxamide (4c, Figure S3). Cream solid; isolated yield: $65 \%$; M.P: $221-224^{\circ} \mathrm{C}$; ${ }^{1} \mathrm{H}$ NMR $\left(500 \mathrm{MHz}, \mathrm{CDCl}_{3}\right) \delta$ ppm: $8.23(\mathrm{~s}, 1 \mathrm{H}), 8.17(\mathrm{~d}, J=8.0 \mathrm{~Hz}$, $1 \mathrm{H}), 8.04(\mathrm{~s}, 1 \mathrm{H}), 7.71(\mathrm{~d}, J=7.5 \mathrm{~Hz}, 1 \mathrm{H}), 7.55(\mathrm{t}, J=8.0 \mathrm{~Hz}$, $1 \mathrm{H}), 6.12(\mathrm{~s}, 1 \mathrm{H}), 5.58(\mathrm{~s}, 1 \mathrm{H}), 3.49-2.95(\mathrm{~m}, 4 \mathrm{H}), 1.81(\mathrm{~s}$, $3 \mathrm{H}), 1.00(\mathrm{t}, J=7.0 \mathrm{~Hz}, 3 \mathrm{H}), 0.66$ (brs, $3 \mathrm{H}) ;{ }^{13} \mathrm{C} \mathrm{NMR}$ $\left(125 \mathrm{MHz}, \mathrm{CDCl}_{3}\right) \delta \mathrm{ppm}: 166.05,152.57,147.56,144.36$, $143.44,132.00,128.88,122.16,120.63,103.62,56.80,41.27$, 15.46, 12.48; MS (EI), $m / z(\%): 332\left(\mathrm{M}^{+}, 19\right), 315(100)$, 176(29), 72(78), 58(33), 42(96); IR (KBr) $v \max \left(\mathrm{cm}^{-1}\right): 3447$, 3233, 3117, 2975, 2938, 1678, 1599, 1531, 1499, 1460, 1434, $1387,1349$.

(4) N,N-Diethyl-6-methyl-4-(4-nitrophenyl)-2-oxo-1,2,3,4-tetrahydropyrimidine-5-carboxamide (4d, Figure S4). Cream solid; isolated yield: $92 \%$; M.P: $220-225^{\circ} \mathrm{C} ;{ }^{1} \mathrm{H}$ NMR $(500 \mathrm{MHz}$, $\left.\mathrm{CDCl}_{3}\right) \delta$ ppm: $8.21(\mathrm{~d}, J=8.5 \mathrm{~Hz}, 2 \mathrm{H}), 8.13(\mathrm{~s}, 1 \mathrm{H}), 7.54(\mathrm{~d}$, $J=8.5 \mathrm{~Hz}, 2 \mathrm{H}), 6.22(\mathrm{~s}, 1 \mathrm{H}), 5.57(\mathrm{~s}, 1 \mathrm{H}), 3.65-2.76(\mathrm{~m}, 4 \mathrm{H})$, 1.78 (s, 3H), 1.02 (s, 3H), 0.63 (brs, 3H); ${ }^{13} \mathrm{C} \mathrm{NMR} \mathrm{(125} \mathrm{MHz,}$ $\left.\mathrm{CDCl}_{3}\right) \delta$ ppm: 166.08, 152.69, 148.24, 146.69, 131.07, 126.62, $123.06,103.42,56.78,41.20,15.41,12.48$; MS (EI), $\mathrm{m} / z(\%)$ : 332 $\left(\mathrm{M}^{+}, 100\right), 260(52), 230(45), 217(37), 72(54), 42(35) \mathrm{IR}$ $(\mathrm{KBr}) v \max \left(\mathrm{cm}^{-1}\right): 3238,3109,2975,2936,1724,1684,1594$, $1522,1458,1384$.

(5) 4-(4-Chlorophenyl)-N,N-diethyl-6-methyl-2-oxo-1,2,3,4tetrahydropyrimidine-5-carboxamide (4e, Figure S5). Cream solid; isolated yield: $73 \%$; M.P: $241-246{ }^{\circ} \mathrm{C}$; ${ }^{1} \mathrm{H}$ NMR $\left(500 \mathrm{MHz} \mathrm{CDCl}_{3}\right) \delta$ ppm: $8.09(\mathrm{~s}, 1 \mathrm{H}), 7.32-7.27(\mathrm{~m}, 4 \mathrm{H})$, 
$5.84(\mathrm{~s}, 1 \mathrm{H}), 5.42(\mathrm{~s}, 1 \mathrm{H}), 3.54-2.83(\mathrm{~m}, 4 \mathrm{H}), 1.75(\mathrm{~s}, 3 \mathrm{H})$, 1.01 (s, 3H), 0.65 (s, 3H); $\left.{ }^{13} \mathrm{C} \mathrm{NMR} \mathrm{(125} \mathrm{MHz,} \mathrm{CDCl}_{3}\right) \delta$ ppm: 166.41, 152.85, 139.86, 132.97, 128.37, 127.92, 127.07, 104.33, 56.78, 41.07, 15.29, 12.29; MS (EI), $m / z(\%): 323$ $\left(\mathrm{M}^{+2}, 37\right), 321\left(\mathrm{M}^{+}, 100\right), 249(55), 221(89), 206(42), 166(53)$, 72(67); IR (KBr) $v \max \left(\mathrm{cm}^{-1}\right): 3446,3231,3131,3101,2975$, 2933, 1704, 1681, 1599, 1489, 1458, 1436, 1407, 1306.

(6) 4-(4-Bromophenyl)-N, N-diethyl-6-methyl-2-oxo-1,2,3,4tetrahydropyrimidine-5-carboxamide (4f, Figure S6). Cream solid; isolated yield: $79 \%$; M.P: $260-264^{\circ} \mathrm{C} ;{ }^{1} \mathrm{H}$ NMR $\left(500 \mathrm{MHz}, \mathrm{CDCl}_{3}\right) \delta$ ppm: $7.92(\mathrm{~s}, 1 \mathrm{H}), 7.48(\mathrm{~d}, J=8.0 \mathrm{~Hz}$, 2H), $7.23(\mathrm{~d}, J=8.0 \mathrm{~Hz}, 2 \mathrm{H}), 5.72(\mathrm{~s}, 1 \mathrm{H}), 5.43$ (s, 1H), 3.43 $(\mathrm{q}, J=7.0 \mathrm{~Hz}, 2 \mathrm{H}), 3.04(\mathrm{q}, J=7.0 \mathrm{~Hz}, 2 \mathrm{H}), 1.77(\mathrm{~s}, 3 \mathrm{H}), 1.02$ $(\mathrm{t}, J=7.0 \mathrm{~Hz}, 3 \mathrm{H}), 0.64(\mathrm{t}, J=7.0 \mathrm{~Hz}, 3 \mathrm{H}) ;{ }^{13} \mathrm{C} \mathrm{NMR}$ $\left(125 \mathrm{MHz}, \mathrm{CDCl}_{3}\right) \delta$ ppm: 166.35, 152.62, 140.27, 130.91, 127.40, 121.12, 114.62, 104.32, 56.90, 41.14, 15.35, 11.37; MS (EI), $m / z(\%): 367\left(\mathrm{M}^{+2}, 45\right) ; 365\left(\mathrm{M}^{+}, 45\right), 293(37), 265(100)$, 210(47), 100(31), 72(77); IR (KBr) $v \max \left(\mathrm{cm}^{-1}\right): 3373,3228$, 3131, 2974, 29333, 1702, 1599, 1486, 1435, 1382.

(7) N,N-Diethyl-4-(4-methoxyphenyl)-6-methyl-2-oxo1,2,3,4-tetrahydropyrimidine-5-carboxamide (4g, Figure S7). Cream solid; isolated yield: $55 \%$; M.P: $248-251{ }^{\circ} \mathrm{C} ;{ }^{1} \mathrm{H}$ NMR (500 MHz, Chloroform- $d$ ) $\delta$ ppm: 8.12 (s, 1H), 7.25 (d, $J=8.5 \mathrm{~Hz}, 2 \mathrm{H}), 6.85(\mathrm{~d}, J=8.5 \mathrm{~Hz}, 2 \mathrm{H}), 5.57(\mathrm{~s}, 1 \mathrm{H}), 5.39(\mathrm{~s}$, $1 \mathrm{H}), 3.79$ (s, 3H), 3.50-2.86 (m, 4H), 1.76 (s, 3H), 1.00 (s, $3 \mathrm{H}), 0.61(\mathrm{~s}, 3 \mathrm{H}) ;{ }^{13} \mathrm{C} \mathrm{NMR}\left(125 \mathrm{MHz}, \mathrm{CDCl}_{3}\right) \delta \mathrm{ppm}$ : 166.71, 158.50, 152.87, 146.29, 133.58, 126.87, 113.09, 105.04, 56.86, 54.34, 41.04, 15.27, 12.22; MS (EI), $m / z(\%): 317\left(\mathrm{M}^{+}\right.$, 100), 302(71), 243(89), 217(100), 203(88), 162(100), 72(95); IR $(\mathrm{KBr}) v \max \left(\mathrm{cm}^{-1}\right): 3366,3234,3102,2972,2933,2840$, 1703, 1598, 1511, 1437, 1382.

(8) N,N-Diethyl-4-(3-hydroxyphenyl)-6-methyl-2-oxo1,2,3,4-tetrahydropyrimidine-5-carboxamide (4h, Figure S8). Cream solid; isolated yield: $53 \%$; M.P: $247-250^{\circ} \mathrm{C} ;{ }^{1} \mathrm{H}$ NMR $\left(500 \mathrm{MHz}, \mathrm{CDCl}_{3}\right) \delta$ ppm: $8.36(\mathrm{~s}, 1 \mathrm{H}), 7.33-7.30(\mathrm{~m}, 4 \mathrm{H})$, 7.28-7.23 (m, 1H), $5.83(\mathrm{~s}, 1 \mathrm{H}), 5.42(\mathrm{~s}, 1 \mathrm{H}), 3.45-2.83(\mathrm{~m}$, $4 \mathrm{H}), 1.73(\mathrm{~s}, 3 \mathrm{H}), 0.99(\mathrm{~s}, 3 \mathrm{H}), 0.51(\mathrm{~s}, 3 \mathrm{H}) ;{ }^{13} \mathrm{C} \mathrm{NMR}$ $\left(125 \mathrm{MHz}, \mathrm{CDCl}_{3}\right) \delta \mathrm{ppm}: 166.67,157.15,153.08,146.36$, $141.41,130.80,127.76,127.10,125.62,104.66,57.38,41.09$, $15.22,13.17$; MS (EI), $m / z(\%): 303\left(\mathrm{M}^{+}, 92\right), 230(68)$, 201(100), 188(44), 147(34), 74(45); IR (KBr) $v \max \left(\mathrm{cm}^{-1}\right)$ : 3271, 3100, 2969, 2936, 1708, 1599, 1438, 1359.

(9) N,N-Diethyl-6-methyl-2-oxo-4-(thiophen-2-yl)-1,2,3,4tetrahydropyrimidine-5-carboxamide (4i, Figure S9). Cream solid; isolated yield: $75 \%$; M.P: $268-273^{\circ} \mathrm{C} ;{ }^{1} \mathrm{H}$ NMR $\left(500 \mathrm{MHz}, \mathrm{CDCl}_{3}\right) \delta \mathrm{ppm}: 13.91(\mathrm{~s}, 1 \mathrm{H}), 7.74(\mathrm{~d}, J=3.5 \mathrm{~Hz}$, $1 \mathrm{H}), 7.61(\mathrm{~d}, J=4.5 \mathrm{~Hz}, 1 \mathrm{H}), 7.12-6.99(\mathrm{~m}, 1 \mathrm{H}), 3.68-3.49$ $(\mathrm{m}, 2 \mathrm{H}), 3.21-3.01(\mathrm{~m}, 2 \mathrm{H}), 2.45(\mathrm{~s}, 3 \mathrm{H}), 1.27(\mathrm{t}, J=7.0 \mathrm{~Hz}$, $3 \mathrm{H}), 0.90(\mathrm{t}, J=7.0 \mathrm{~Hz}, 3 \mathrm{H}) ;{ }^{13} \mathrm{C} \mathrm{NMR}\left(125 \mathrm{MHz}, \mathrm{CDCl}_{3}\right) \delta$ ppm: 164.91, 157.66, 147.26, 145.92, 132.25, 130.75, 127.48, $111.20,51.12,42.28,16.50,12.68$; MS (EI), $m / z(\%): 293\left(\mathrm{M}^{+}\right.$, 6), 258(52), 219(100), 178(59), 110(69), 72(56); IR (KBr) $v \max \left(\mathrm{cm}^{-1}\right): 3447,3233,3117,2975,2938,1678,1599,1531$, 1499, 1460, 1387.
2.2. Molecular Docking Details. Molecular docking was carried out to study the interactions between the most potent compound and the active site of the enzyme (1BHG, apo human $\beta$-glucuronidase) using AutoDock tools. The twodimensional structure of $4 \mathbf{i}$ was sketched and optimized using HyperChem and was saved in PDB format. Before docking, the PDB file was converted into pdbqt format using AutoDock Tools while adding Gasteiger charges, polar hydrogen atoms, and merged nonpolar hydrogen atoms. The compound was docked into the active site of $\beta$-glucuronidase using default parameters 100 runs for each ligand, 27000 as the maximum number of generations. The grid box was set with 30,30 , and 30 points with the center of $84.55,77.88$, and 91.26 in the $x, y$, and $z$ directions, respectively. All other options were set as default.

2.3. Molecular Dynamics Simulation. The molecular dynamics simulation of compound $\mathbf{4 i}$ in complex with human $\beta$-glucuronidase, PID: $1 \mathrm{BHG}$, was carried out using the AMBER 18 molecular dynamics package on a Centos Linux server equipped with GPUs. Amber99sb force field was applied to define the atom types and dynamics simulation parameters. An octahedral box was defined around the solute and was filled with the TIP3P water molecules and the appropriate number of $\mathrm{Na}+$ ions replaced water molecules to neutralize the system. Then, the system was targeted to energy minimization in explicit solvent by the steepest descent algorithm once with restraints and once without restraints. Then, NVT heating with putting restraints on the solute was carried out during a 500 ps time so that solvent molecules and counter-ions immersed the macromolecule. During NVT step, the temperature was controlled near to $300 \mathrm{~K}$. The periodic boundary simulations based on the particle mesh Ewald (PME) method were applied and the SHAKE algorithm was used to constrain the covalent bond lengths. Then, under the 500 ps NPT ensemble equilibration phase, the pressure of the system was regulated with an average pressure of $1 \mathrm{~atm}$ in such a way that the density of water could relax. Isotropic position scaling was applied to preserve the pressure periodic boundary constant. The production MD run was performed for $100 \mathrm{~ns}$ simulation time on the well-equilibrated system at $300 \mathrm{~K}$ and pressure of $1 \mathrm{~atm}$. After termination, the trajectory was corrected for periodic boundary conditions and was downsampled to maintain 1000 frames for any postanalysis. To define the equilibrium time range, the root-mean-square deviation (RMSD) $\AA$ for the protein backbone atoms of each snapshot was then calculated during the simulation run time against the first frame. All interaction analysis and image preparations were performed by Discovery Studio Visualizer v20.1.0.19295.

2.4. $\beta$-Glucuronidase Bioassay. $\beta$-glucuronidase inhibitory activity was determined by monitoring the absorbance of p-nitrophenol formed from the substrate at $405 \mathrm{~nm}$ by the spectrophotometric method according to the literature report. Briefly, to a 96-well microplate, $185 \mu \mathrm{l}$ of $0.1 \mathrm{M}$ acetate buffer $(\mathrm{pH}=7.0)$ and $5 \mu \mathrm{l}$ of test compound (3X concentration) were added and gently mixed. Then, $10 \mu \mathrm{l}$ of $2.5 \mathrm{unit} / \mathrm{mL}$ 
enzyme was added to start the reaction. After incubation for 30 minutes at room temperature, $50 \mu \mathrm{L}$ of $0.4 \mathrm{mM}$ para nitrophenyl-b-d-glucuronide as substrate was added and the absorbance was measured. DMSO was used to dissolve the test compound ( $3 \mathrm{X}$ concentration). The $\mathrm{IC}_{50}$ values were determined graphically from inhibition curves (log inhibitor concentration vs. percent of inhibition) $[28,29]$.

\section{Results and Discussion}

3.1. Designing. Several pharmacologically active structural units, including benzohydrazone-oxadiazole (Figure 1, compound A) [30], bisindole (Figure 1, compound B) [31], oxadiazoles (Figure 1, compound C) [32], benzothiazole (Figure 1, compound D) [33], imidazole (Figure 1, compound E) [14], and quinolones (Figure 1, compound F) [29], are being identified as novel synthesized anti- $\beta$-glucuronidase molecules.

In 2016, Ali et al. introduced dihydropyrimidones derivatives as a novel class of $\beta$-glucuronidase inhibitors via a "one-pot" three-component reaction. In vitro, SAR evaluation confirmed that polar groups with hydrogen bonding interactions have better inhibitory activity compared to the rest of synthesized compounds. The most potent compounds containing para-trifluoromethyl group (Figure 1, compound G) showed good inhibitory potential $\left(\mathrm{IC}_{50}=9.38 \pm 0.15 \mu \mathrm{M}\right)$ compared to the standard drug d-saccharic acid 1,4-lactone $\left(\mathrm{IC}_{50}=48.4 \pm 1.25 \mu \mathrm{M}\right)$.

Previously, our research group reported thioxo-tetrahydropyrimidine as potent $\beta$-glucuronidase inhibitors with $\mathrm{IC}_{50}$ values ranging from 0.35 to $42.05 \mu \mathrm{M}$. The most potent compound in this series was compound $\mathbf{H}$ (Figure 1) bearing the thiophene motif. It was also concluded that meta substitutions on phenyl ring are more favorable to anti- $\beta$ glucuronidase activity. The SARs indicated that the thiophene ring is important for inhibiting the $\beta$-glucuronidase. Molecular dynamics suggested that hydrogen bonds interaction with Tyr205, Asp207, and Glu451 with $\beta$-glucuronidase results in conformational stability which justifies the high potency of the mentioned compound [28].

The literature review has shown that the introduction/ modification of specific groups on heterocyclic moiety may change their biological activities. Some structural modifications were planned based on single-point replacement on compound $\mathrm{H}$ (Figure 1) via replacing the thio atom with oxo while keeping diethyl acetamide linker in the structure with the hope to enhance their $\beta$-glucuronidase inhibitory potential and $\mathrm{H}$-bound interactions. Additionally, the structure-activity relationship (SAR) and molecular docking study against $\beta$-glucuronidase were discussed.

3.2. Chemistry. Dihydropyrimidinone analogs 4a-i were synthesized by treating commercially available $\beta$-ketoamide with different aldehydes in acetonitrile (Scheme 1). In a typical reaction, to a stirring mixture of N,N-diethyl-3oxobutanamide (1) and thiourea (2), different substituted aromatic aldehydes (3) were added. The mixture was refluxed in the presence of $\mathrm{FeCl}_{3} \cdot 6 \mathrm{H}_{2} \mathrm{O}$. Reaction progress was checked by monitoring thin layer chromatography (TLC). After the completion of the reaction, the solid product was washed and recrystallized from ethanol to afford the pure products.

3.3. Enzyme Inhibitory Study. Dihydropyrimidinone analogs (4a-i) with different substitutions at $\mathrm{R}$ position demonstrating $\beta$-glucuronidase inhibition ranged from 31.52 to $\geq 100 \mu \mathrm{M}$ compared with the standard drug d-saccharic acid 1,4-lactone $\left(\mathrm{IC}_{50}=41.32 \mu \mathrm{M}\right)$. The SAR mainly depended on different moiety on the phenyl pendant (Table 1).

The non-substituted derivative (4a) did not show any activity in the tested concentrations. Compared with compound $\mathbf{4 a}$ as the unsubstituted compound, superior inhibitory activity was observed in nitrophenyl derivatives (4b, 4c, and 4d). The order of potency in this series was as follows: meta $\left(4 \mathrm{c}, \mathrm{IC}_{50}=42.19 \pm 3.27 \mu \mathrm{M}\right)>$ para $\left(4 \mathrm{c}, \mathrm{IC}_{50}=52.48\right.$ $\pm 4.81 \mu \mathrm{M})>$ ortho $\left(4 \mathrm{~b}, \mathrm{IC}_{50}=87.25 \pm 4.13 \mu \mathrm{M}\right)$. To investigate the influence of halogen substitution at the para position of the phenyl moiety, compounds $\mathbf{4 e}$ and $\mathbf{4 f}$ were also synthesized. The in vitro biological results demonstrated approximately similar $\beta$-glucuronidase inhibitory potency for both derivatives compared to $4 a\left(4 \mathrm{e}, \mathrm{IC}_{50}=91.27 \pm\right.$ $4.67 \mu \mathrm{M}$, and $\left.4 \mathrm{f}, \mathrm{IC}_{50}>100 \mu \mathrm{M}\right)$. The introduction of the 4-methoxy group at the $\mathrm{R}$ position slightly increased the activity $\left(4 \mathrm{~g}, \mathrm{IC}_{50}=73.12 \pm 2.69\right)$ compared to an unsubstantiated one (4a). Position and bioisosteric replacement of 4-methoxy with 3-hydroxy (4h) substitution on phenyl ring contributed to a better $\beta$-glucuronidase inhibitory activity with an $\mathrm{IC}_{50}$ value of $46.33 \pm 4.13 \mu \mathrm{M}$. In most cases, the para-substitution on the phenyl ring was found to be weakly active, while switching from para to meta, better inhibitory potential was observed. $4 \mathbf{i}$ containing thiophene moiety with $\mathrm{IC}_{50}=31.52 \mu \mathrm{M}$ emerged as the most active inhibitor of the series, producing a substantial improvement of $\beta$-glucuronidase inhibitorypotential.

3.4. Molecular Docking Interactions. Interactions of the most potent compound $\mathbf{4 i}$ within the active site of the target protein are shown in Figures 2(a) and 2(b). The Asn484 and Lys606 of $\beta$-glucuronidase showed hydrogen bond interactions via oxygen in amide and nitrogen in pyrimidine of $4 \mathbf{i}$ with a distance of 2.95 and $2.55 \AA$, respectively. Compound $4 i$ also made two other hydrogen bonds with Asp207 and Tyr504. Asp207 was involved in pi-sigma hydrophobic interaction with the thiophene ring $(3.72 \AA)$. The other in pisigma hydrophobic interaction with a distance of $3.66 \AA$ was observed between diethylamide and Tyr508. It seems that in vitro inhibition potential of $\mathbf{4 i}$ against $\beta$-glucuronidase was supported by performing molecular docking studies. Docking scores and the predicted interactions of top-ranked confirmation of all derivatives are reported in Table 2 which showed the consistency of computational and biological results. 


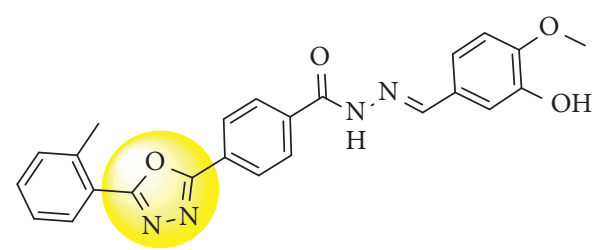

(a)<smiles>Oc1cc(O)c(-c2nc3ccccc3s2)cc1O</smiles>

(d)<smiles>COC(=O)C1=C(C)NC(=O)NC1c1ccc(C(F)(F)F)cc1</smiles>

(g)

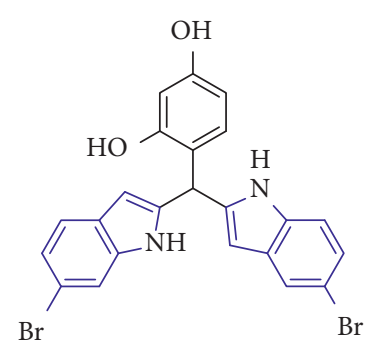

(b)<smiles>Cc1ncc(N)n1CCOC(=O)c1cc(F)c(F)cc1F</smiles>

(e)<smiles>CCN(CC)C(=O)C1=C(C)NC(=S)NC1c1cccs1</smiles>

(h)<smiles>COc1ccc(-c2nnc(-c3ccc(-c4nc5cc(C)c(C)cc5[nH]4)cc3)o2)cc1</smiles>

(c)<smiles>O=S(=O)(Nc1cccc2ncccc12)c1cc(Cl)cc(Cl)c1O</smiles>

(f)<smiles>[R][R]c1ccccc1C1NC(=O)NC(C)=C1C(=O)N(CC)CC</smiles>

(i)

FIGURE 1: Identified leads for $\beta$-glucuronidase inhibition. (a) $\mathrm{IC}_{50}=7.17 \pm 0.30 \mu \mathrm{M}$, (b) $\mathrm{IC}_{50}=7.62 \pm 0.04 \mu \mathrm{M},(\mathrm{c}) \mathrm{IC}_{50}=2.14 \pm 0.03 \mu \mathrm{M}$, (d) $\mathrm{IC}_{50}=2.26 \pm 0.06 \mu \mathrm{M}$, (e) $\mathrm{IC}_{50}=1.20 \pm 0.01 \mu \mathrm{M}$, (f) $\mathrm{IC}_{50}=1.60 \pm 0.10 \mu \mathrm{M},(\mathrm{g}) \mathrm{IC}_{50}=9.38 \pm 0.15 \mu \mathrm{M}$, (h) $\mathrm{IC}_{50}=0.35 \pm 0.09 \mu \mathrm{M}$, (i) new design scaffold.

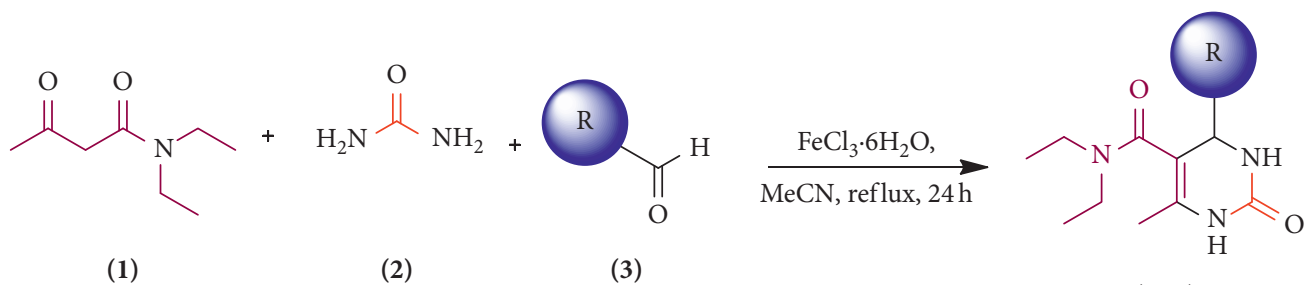

$(1)$

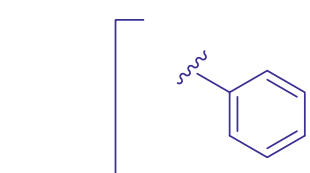

$\mathrm{R}=$ 4a<smiles>O=[N+]([O-])c1ccccc1O</smiles>

$4 \mathrm{~b}$<smiles>O=[N+]([O-])c1cccc(I)c1</smiles>

$4 c$<smiles>O=[N+]([O-])c1ccc(I)cc1</smiles>

$4 d$<smiles>Clc1ccc(I)cc1</smiles>

$4 e$

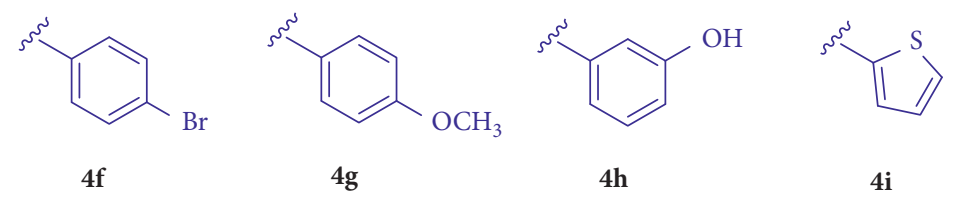

Scheme 1: Synthetic routes to the dihydropyrimidinone series $(\mathbf{4 a - i})$. 
TABLE 1: $\beta$-glucuronidase inhibitory activity of the dihydropyrimidinone derivatives.

\begin{tabular}{|c|c|c|}
\hline Compound & $\mathrm{R}$ & $\mathrm{IC}_{50}(\mu \mathrm{M} \pm \mathrm{SE})^{\mathrm{a}}$ \\
\hline $4 a$ & & $>100$ \\
\hline $4 b$ & & $87.25 \pm 4.13$ \\
\hline $4 c$ & & $42.19 \pm 3.27$ \\
\hline $4 d$ & & $52.48 \pm 4.81$ \\
\hline $4 e$ & & $91.27 \pm 4.67$ \\
\hline $4 f$ & & $>100$ \\
\hline $4 \mathrm{~g}$ & & $73.12 \pm 2.69$ \\
\hline $4 \mathrm{~h}$ & & $46.33 \pm 4.13$ \\
\hline $4 \mathbf{i}$ & & $31.52 \pm 2.54$ \\
\hline D-saccharic acid 1,4-lactone ${ }^{b}$ & & $41.32 \pm 1.82$ \\
\hline
\end{tabular}

${ }^{\mathrm{a}} \mathrm{IC}_{50}$ values are expressed as mean \pm standard error of the mean. ${ }^{\mathrm{b}}$ Standard inhibitor for $\beta$-glucuronidase.

3.5. Molecular Dynamics Simulation. The trajectory stability was examined via RMSD analysis of the protein backbone atoms against the primary conformation calculated for the complex; see Figure 3(a). The RMSD value mounted rapidly from zero for the initial frame, and afterward formed a regular profile after nearly $10 \mathrm{~ns}$. The number of formed hydrogen bonds during the simulation time between ligand $4 \mathbf{i}$ and protein residues was also monitored; see Figure 3(b). The maximum number of hydrogen bonds made was 3 and in $37.5 \%$ of simulation time there was at least one hydrogen bond between the ligand and protein residues.

The interaction pattern of compound $4 \mathbf{i}$ is shown in Figure 4 . There were three hydrogen bonds with residues
Glu451, Asn502, and Glu540. Two NHs in tetrahydropyrimidine-2-one group donated two hydrogen bonds to Glu451 and Glu540 while carbonyl of this group accepted one hydrogen bond from Asn502. Sulfur in thiophene participated in a pi-sulfur interaction with Trp587. Residue His385 took part in a pi-pi stacked interaction with thiophene which along with hydrogen bond interactions enhanced the affinity of compound $\mathbf{4 i}$ in the $\beta$-glucuronidase active site. One of the ethanamine groups and the methyl attached to the tetrahydropyrimidine-2-one group were subjected to the solvent and did not show any interaction with protein. As a comparison to our previous study on thioxo-tetrahydropyrimidine derivatives [28], thiourea with 


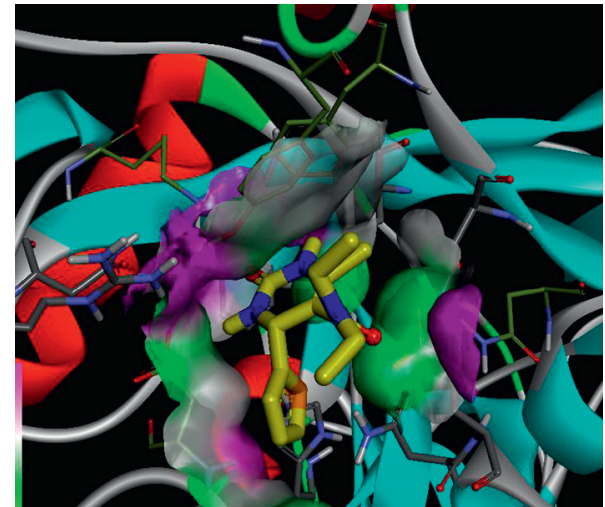

(a)

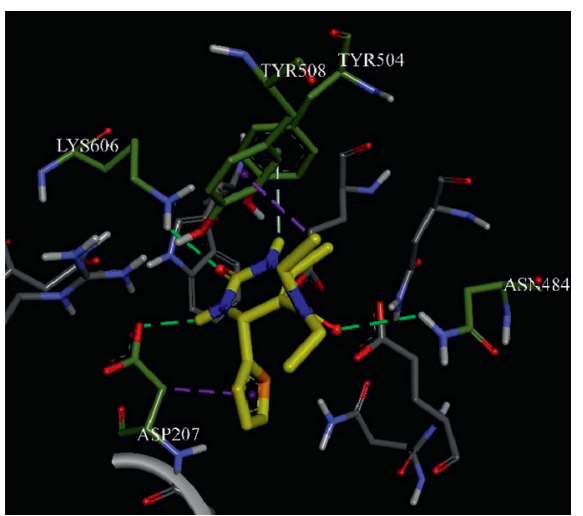

(b)

Figure 2: The binding orientation (a) and interactions (b) of compound $\mathbf{4} \mathbf{i}$ into the $\beta$-glucuronidase enzyme. Ligand $4 \mathbf{i}$ is displayed as yellow sticks, while the core amino acid residues are shown as green sticks. Hydrogen bonding and Pi-Pi interactions are displayed as green and pink, respectively.

TABLE 2: Docking energies and interactions of compounds against the $\beta$-glucuronidase enzyme.

\begin{tabular}{|c|c|c|c|c|c|}
\hline Compound & $\Delta G(\mathrm{kcal} / \mathrm{Mol})$ & Category (type) & Ligand involved moiety & Receptor involved part & Distance $(\AA)$ \\
\hline $4 \mathrm{a}$ & -6.0 & Hydrophobic (pi-pi stacked) & Phenyl ring & Tyr508 & 4.39 \\
\hline \multirow{4}{*}{$4 b$} & \multirow{4}{*}{-6.7} & Hydrogen bond & $\mathrm{O}(\mathrm{C}=\mathrm{O}$ pyrimidinone ring $)$ & Lys606 & 2.33 \\
\hline & & Hydrogen bond & $\mathrm{H}$ (N-H pyrimidinone ring) & Glu540 & 2.74 \\
\hline & & Hydrogen bond & $\mathrm{H}(\mathrm{N}-\mathrm{H}$ pyrimidinone ring) & Asp207 & 2.07 \\
\hline & & Hydrophobic (pi-sigma) & C-H (Et) & Tyr508 & 3.78 \\
\hline \multirow{3}{*}{$4 c$} & \multirow{3}{*}{-7.1} & Hydrogen bond & $\mathrm{O}\left(\mathrm{NO}_{2}\right)$ & His385 & 2.105 \\
\hline & & Hydrogen bond & $\mathrm{O}\left(\mathrm{NO}_{2}\right)$ & Asn 450 & 1.85 \\
\hline & & Hydrogen bond & $\mathrm{C}-\mathrm{H}(\mathrm{Et})$ & Asp207 & 3.43 \\
\hline \multirow{4}{*}{$4 d$} & \multirow{4}{*}{-7.1} & Hydrogen bond & $\mathrm{O}\left(\mathrm{NO}_{2}\right)$ & Asp207 & 1.98 \\
\hline & & Hydrogen bond & $\mathrm{O}\left(\mathrm{NO}_{2}\right)$ & His385 & 2.21 \\
\hline & & Hydrogen bond & $\mathrm{O}\left(\mathrm{NO}_{2}\right)$ & Asn 450 & 2.26 \\
\hline & & Hydrogen bond & $\mathrm{O}(\mathrm{C}=\mathrm{O}$ amide $)$ & Asn 484 & 2.38 \\
\hline \multirow{5}{*}{$4 e$} & \multirow{5}{*}{-6.7} & Hydrogen bond & $\mathrm{O}(\mathrm{C}=\mathrm{O}$ pyrimidinone ring $)$ & Trp507 & 2.75 \\
\hline & & Hydrophobic (pi-pi stacked) & Phenyl ring & Trp507 & 4.25 \\
\hline & & Hydrophobic (pi-pi stacked) & Phenyl ring & Trp507 & 3.69 \\
\hline & & Hydrophobic (pi-alkyl) & $\mathrm{Cl}$ & Trp507 & 4.27 \\
\hline & & Hydrophobic (pi-alkyl) & $\mathrm{Cl}$ & Tyr561 & 4.23 \\
\hline \multirow{2}{*}{$4 f$} & \multirow{2}{*}{-6.1} & Hydrophobic (pi-sigma) & C-H (Et) & $\operatorname{Trp587}$ & 3.87 \\
\hline & & Hydrophobic (pi-pi stacked) & Phenyl ring & Tyr508 & 4.53 \\
\hline \multirow{3}{*}{$4 \mathrm{~g}$} & \multirow{3}{*}{-6.6} & Hydrogen bond & C-H (Et) & Tyr508 & 3.24 \\
\hline & & Hydrophobic (pi-sigma) & $\mathrm{C}-\mathrm{H}(\mathrm{Et})$ & $\operatorname{Trp} 587$ & 3.88 \\
\hline & & Hydrophobic (pi-pi stacked) & Phenyl ring & Tyr508 & 4.37 \\
\hline \multirow{6}{*}{$4 h$} & \multirow{6}{*}{-7.0} & Hydrogen bond & $\mathrm{OH}$ & His385 & 2.82 \\
\hline & & Hydrogen bond & $\mathrm{O}(\mathrm{C}=\mathrm{O}$ pyrimidinone ring $)$ & Asn 484 & 2.15 \\
\hline & & Hydrogen bond & $\mathrm{O}(\mathrm{C}=\mathrm{O}$ amide $)$ & Tyr508 & 2.43 \\
\hline & & Hydrogen bond & $\mathrm{H}$ (pyrimidinone ring) & Tyr508 & 3.25 \\
\hline & & Hydrogen bond & $\mathrm{C}-\mathrm{H}(\mathrm{Et})$ & Asp207 & 3.39 \\
\hline & & Hydrophobic (pi-pi T-shaped) & Phenyl ring & Trp587 & 5.38 \\
\hline \multirow{6}{*}{$4 \mathbf{i}$} & \multirow{6}{*}{-7.2} & Hydrogen bond & $\mathrm{O}(\mathrm{C}=\mathrm{O}$ amide $)$ & Asn 484 & 2.95 \\
\hline & & Hydrogen bond & $\mathrm{O}(\mathrm{C}=\mathrm{O}$ pyrimidinone ring $)$ & Lys606 & 2.55 \\
\hline & & Hydrogen bond & $\mathrm{H}$ (N-H pyrimidinone ring) & Asp207 & 2.25 \\
\hline & & Hydrogen bond & $\mathrm{H}$ (N-H pyrimidinone ring) & Tyr504 & 3.36 \\
\hline & & Hydrophobic (pi-sigma) & Thiophene ring & Asp207 & 3.72 \\
\hline & & Hydrophobic (pi-sigma) & C-H (Et) & Typ508 & 3.66 \\
\hline
\end{tabular}




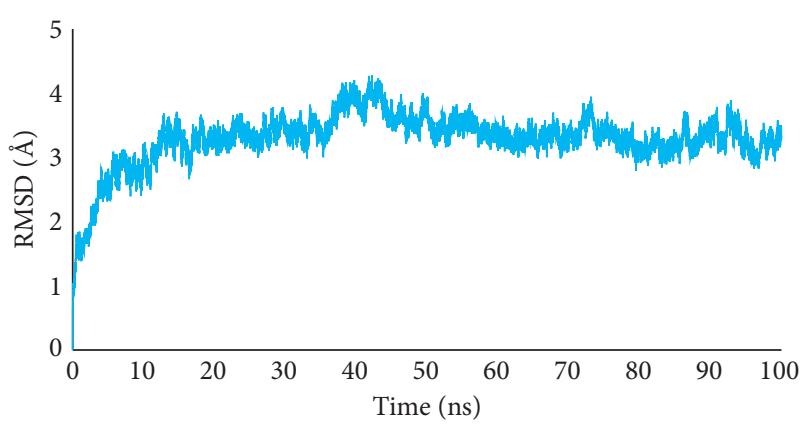

(a)

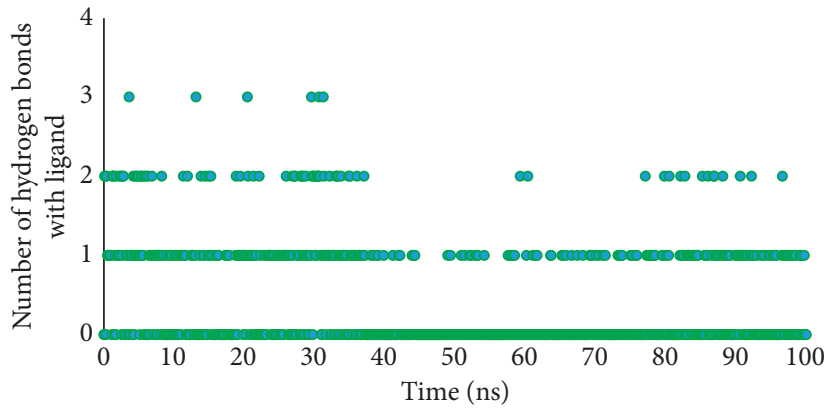

(b)

FIGURE 3: RMSD evolution of the protein backbone atoms of the complex (a) number of hydrogen bonds made between protein residues and the ligand $4 \mathbf{i}(\mathrm{b})$.

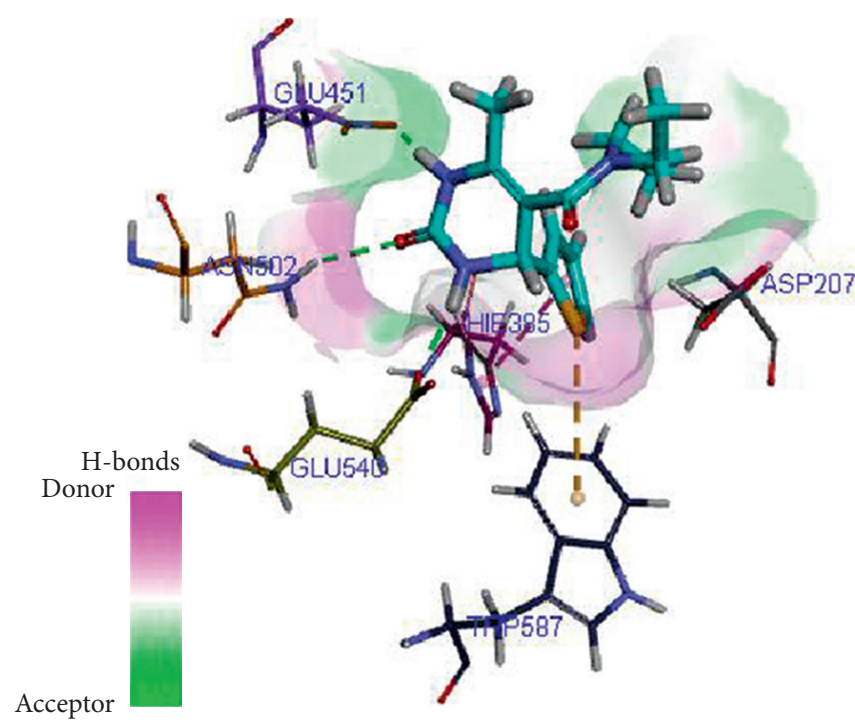

(a)
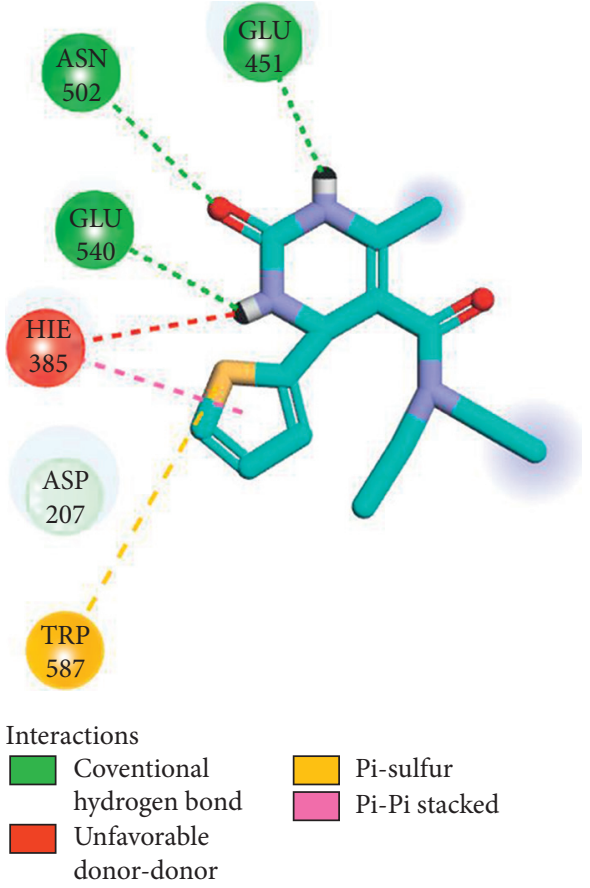

(b)

FIGURE 4: Interaction pattern of compound $\mathbf{4} \mathbf{i}$ inside the $\beta$-glucuronidase enzyme. 3D interactions of ligand within a hydrogen bond protein surface (a) and 2D interactions (b) figures were generated by Discovery Studio Visualizer v20.1.0.19295.

the sulfur atom in compound $\mathbf{4 g}$ substituted by oxygen in $\mathbf{4 i}$. Sulfur has a larger van der Waal radius with less electronegativity in comparison to oxygen that makes its electronegative interactions weaker and more transient. This lets the structure to move easier towards residues with hydrogen bonding abilities and avoid unfavorable interactions. Herein, compound $\mathbf{4} \mathbf{i}$ showed an unfavorable donor-donor interaction with His385 and generally, this compound has made fewer number of hydrogen bonds throughout the simulation time in comparison to compound $\mathbf{4 g}$ in our previous study.

3.6. In Silico ADME Evaluation. In silico ADME/Tox studies of the synthesized compounds were performed using http:// biosig.unimelb.edu.au/pkcsm/prediction server. Based on results reported in Table 3, all compounds pass the Lipinski's rule of $5(\mathrm{MW}<500, \operatorname{cog} \mathrm{P}<5, \mathrm{HB}$ donor $\leq 5, \mathrm{HB}$ acceptor $\leq 10)$. 
TABLE 3: Calculated molecular profile for synthesized compounds 4a-i

\begin{tabular}{|c|c|c|c|c|c|c|c|c|}
\hline Compound & Mw & cLogP & Rotatable bonds & H-bond acceptor & H-bond donor & Surface area & Hepatotoxicity & Skin sensitization \\
\hline $4 a$ & 287.363 & 2.18 & 4 & 2 & 2 & 124.57 & No & No \\
\hline $4 b$ & 332.36 & 2.09 & 5 & 4 & 2 & 139.22 & No & No \\
\hline $4 c$ & 332.36 & 2.09 & 5 & 4 & 2 & 139.22 & No & No \\
\hline $4 d$ & 332.36 & 2.09 & 5 & 4 & 2 & 139.22 & No & No \\
\hline $4 e$ & 321.81 & 2.83 & 4 & 2 & 2 & 134.87 & No & No \\
\hline $4 f$ & 366.26 & 2.95 & 4 & 2 & 2 & 138.44 & No & No \\
\hline $4 g$ & 317.39 & 2.19 & 5 & 3 & 2 & 136.05 & Yes & No \\
\hline $4 \mathrm{~h}$ & 303.36 & 1.89 & 4 & 3 & 3 & 129.36 & No & No \\
\hline $4 i$ & 293.39 & 2.24 & 4 & 3 & 2 & 122.21 & No & No \\
\hline
\end{tabular}

\section{Conclusion}

Here, a series of dihydropyrimidinones derivatives as $\beta$-glucuronidase inhibitors were designed and synthesized. Newly synthesized compounds depicted various degrees of $\beta$-glucuronidase inhibitory potential. Amongst, the key structural feature that enabled better $\beta$-glucuronidase inhibition was presented in compound $4 \mathbf{i}$ possessing thiophene ring at $\mathrm{R}$ position with an $\mathrm{IC}_{50}$ value of $31.52 \mu \mathrm{M}$. Also, plausible SAR suggested that the introduction of a meta group on the phenyl ring in comparison with para is more beneficial for $\beta$-glucuronidase inhibition. SAR assessment for thioxo-tetrahydropyrimidine derivatives of our previous work with $\mathrm{IC}_{50}$ value ranging from 0.35 to $42.05 \mu \mathrm{M}$ [28] and the present study (4a-i dihydropyrimidinones analogs) with $\mathrm{IC}_{50}$ of 31.52 to $>100$ confirmed the favorable role of thioxo-tetrahydropyrimidine scaffold compared to dihydropyrimidinone ring. Interestingly, in both sets of compounds, analogs bearing thiophene substituent demonstrated superior $\beta$-glucuronidase inhibitory potency compared to the rest of the derivatives.

These results were also supported by molecular docking and dynamics studies demonstrating efficient binding interaction between the compound $4 \mathrm{i}$ and $\beta$-glucuronidase.

\section{Data Availability}

The datasets used and analyzed during the current study are available from the corresponding author on reasonable request. All data are in the form of tables and figures.

\section{Disclosure}

This study was part of the Pharm.D thesis of Yasaman Moghdani.

\section{Conflicts of Interest}

All authors state that there are no conflicts of interest.

\section{Acknowledgments}

The authors wish to thank the support of the Vice-Chancellor for the Research of Shiraz University of Medical Sciences (grant number: 98-01-12-20785). This agency was not involved in the design of the study and collection, analysis, and interpretation of data as well as in writing the manuscript.

\section{Supplementary Materials}

${ }^{1} \mathrm{H}-\mathrm{NMR},{ }^{13} \mathrm{C}-\mathrm{NMR}$, mass, and IR data are provided for the synthesized compounds. (Supplementary Materials)

\section{References}

[1] J. H. Grubb, C. Vogler, and W. S. Sly, "New strategies for enzyme replacement therapy for lysosomal storage diseases," Rejuvenation Research, vol. 13, no. 2-3, pp. 229-236, 2010.

[2] H. Naz, A. Islam, A. Waheed, W. S. Sly, F. Ahmad, and M. I. Hassan, "Human $\beta$-glucuronidase: structure, function, and application in enzyme replacement therapy," Rejuvenation Research, vol. 16, no. 5, pp. 352-363, 2013.

[3] J. P. Goff, N. J. Koszewski, J. S. Haynes, and R. L. Horst, "Targeted delivery of vitamin $\mathrm{D}$ to the colon using $\beta$-glucuronides of vitamin D: therapeutic effects in a murine model of inflammatory bowel disease," American Journal of Physiology-Gastrointestinal and Liver Physiology, vol. 302, no. 4, pp. G460-G469, 2012.

[4] A. M. Montaño, N. Lock-Hock, R. D. Steiner et al., "Clinical course of sly syndrome (mucopolysaccharidosis type VII)," Journal of Medical Genetics, vol. 53, no. 6, pp. 403-418, 2016.

[5] K. M. Khan, N. Ambreen, M. Taha et al., "Structure-based design, synthesis and biological evaluation of $\beta$-glucuronidase inhibitors," Journal of Computer-Aided Molecular Design, vol. 28, no. 5, pp. 577-585, 2014.

[6] A. LoGuidice, B. D. Wallace, L. Bendel, M. R. Redinbo, and U. A. Boelsterli, "Pharmacologic targeting of bacterial $\beta$-glucuronidase alleviates nonsteroidal anti-inflammatory drug-induced enteropathy in mice," Journal of Pharmacology and Experimental Therapeutics, vol. 341, no. 2, pp. 447-454, 2012.

[7] K. A. O’Leary, A. J. Day, P. W. Needs, F. A. Mellon, N. M. O'Brien, and G. Williamson, "Metabolism of quercetin7 -and quercetin-3-glucuronides by an in vitro hepatic model: the role of human $\beta$-glucuronidase, sulfotransferase, catecholO-methyltransferase and multi-resistant protein 2 (MRP2) in flavonoid metabolism," Biochemical Pharmacology, vol. 65, no. 3, pp. 479-491, 2003.

[8] K. Shimoi and T. Nakayama, "Glucuronidase deconjugation in inflammation," Methods in Enzymology, vol. 400, pp. 263-272, 2005.

[9] B. Sperker, U. Werner, T. E. Mürdter et al., "Expression and function of $\beta$-glucuronidase in pancreatic cancer: potential role in drug targeting," Naunyn-Schmiedeberg's Archives of Pharmacology, vol. 362, no. 2, pp. 110-115, 2000. 
[10] C.-P. Sun, J.-K. Yan, J. Yi et al., "The study of inhibitory effect of natural flavonoids toward $\beta$-glucuronidase and interaction of flavonoids with $\beta$-glucuronidase," International Journal of Biological Macromolecules, vol. 143, pp. 349-358, 2020.

[11] J. Pabba, N. Mohal, and A. Vasella, "Synthesis of glucuronic, mannuronic, and galacturonic acid-derived imidazoles as inhibitors of bovine liver $\beta$-glucuronidase," Helvetica Chimica Acta, vol. 89, no. 7, pp. 1373-1386, 2006.

[12] Y. Watanabe, R. Muroi, H. Tsuchiya, Y. Uda, and K. Hashimoto, "Inhibitory effect of methyl methanethiosulfinate on $\beta$-glucuronidase activity," Bioscience, Biotechnology, and Biochemistry, vol. 77, no. 11, pp. 23252327, 2013.

[13] S.-B. Shim, N.-J. Kim, and D.-H. Kim, " $\beta$-Glucuronidase inhibitory activity and hepatoprotective effect of $18 \beta$-glycyrrhetinic acid from the rhizomes of Glycyrrhiza uralensis," Planta Medica, vol. 66, no. 1, pp. 40-43, 2000.

[14] U. Salar, K. M. Khan, M. Taha et al., "Biology-oriented drug synthesis (BIODS): in vitro $\beta$-glucuronidase inhibitory and in silico studies on 2-(2-methyl-5-nitro-1H-imidazol-1-yl) ethyl aryl carboxylate derivatives," European Journal of Medicinal Chemistry, vol. 125, pp. 1289-1299, 2017.

[15] I. Ali, A. Khan, A. Hussain et al., "Comparative enzyme inhibition study of 1-deazapurines," Medicinal Chemistry Research, vol. 25, no. 11, pp. 2599-2606, 2016.

[16] K. M. Khan, M. Khan, N. Ambreen et al., "Synthesis and $\beta$-glucuronidase inhibitory potential of benzimidazole derivatives," Medicinal Chemistry, vol. 8, no. 3, pp. 421-427, 2012.

[17] K. M. Khan, A. Karim, S. Saied et al., "Evaluation of the thiazole Schiff bases as $\$ \$$ lupbeta $\$ \$ \beta$-glucuronidase inhibitors and their in silico studies," Molecular Diversity, vol. 18, no. 2, pp. 295-306, 2014.

[18] U. Salar, M. Taha, N. H. Ismail et al., "Thiadiazole derivatives as new class of $\beta$-glucuronidase inhibitors," Bioorganic \& Medicinal Chemistry, vol. 24, no. 8, pp. 1909-1918, 2016.

[19] S. K. Rathwa, M. S. Vasava, M. N. Bhoi, M. A. Borad, and H. D. Patel, "Recent advances in the synthesis of C-5substituted analogs of 3,4-dihydropyrimidin-2-ones: a review," Synthetic Communications, vol. 48, no. 9, pp. 963-994, 2018.

[20] R. P. Gore and A. P. Rajput, "A review on recent progress in multicomponent reactions of pyrimidine synthesis," Drug Invention Today, vol. 5, no. 2, pp. 148-152, 2013.

[21] E. P. Carreiro, A. M. Sena, A. Puerta, J. M. Padrón, and A. J. Burke, "Synthesis of novel 1,2,3-triazole-dihydropyrimidinone hybrids using multicomponent 1,3-dipolar cycloaddition (Click)-Biginelli reactions: anticancer activity," Synlett, vol. 31, no. 6, pp. 615-621, 2020.

[22] S. Viveka, G. K. Dinesha, G. K. Nagaraja et al., "One pot synthesis of thiazolo[2,3-b]dihydropyrimidinone possessing pyrazole moiety and evaluation of their anti-inflammatory and antimicrobial activities," Medicinal Chemistry Research, vol. 27, no. 1, pp. 171-185, 2018.

[23] A. Singadi and K. Venkateswarlu, "Synthesis of piperonal based dihydropyrimidinones and evaluation for possible," Anticonvulsant and Antibacterial Activities, vol. 6, no. 1, pp. 4-9, 2020.

[24] Â. De Fátima, T. C. Braga, L. D. S. Neto et al., "A mini-review on Biginelli adducts with notable pharmacological properties," Journal of Advanced Research, vol. 6, no. 3, pp. 363-373, 2015.

[25] P. Awolade, N. Cele, N. Kerru, L. Gummidi, E. Oluwakemi, and P. Singh, "Therapeutic significance of $\beta$-glucuronidase activity and its inhibitors: a review," European Journal of Medicinal Chemistry, vol. 187, Article ID 111921, 2020.

[26] F. Ali, K. M. Khan, U. Salar et al., "Dihydropyrimidones: as novel class of $\beta$-glucuronidase inhibitors," Bioorganic \& Medicinal Chemistry, vol. 24, no. 16, pp. 3624-3635, 2016.

[27] A. Barakat, M. S. Islam, A. M. Al-Majid et al., "Synthesis of pyrimidine-2,4,6-trione derivatives: anti-oxidant, anti-cancer, $\alpha$-glucosidase, $\beta$-glucuronidase inhibition and their molecular docking studies," Bioorganic Chemistry, vol. 68, pp. 72-79, 2016.

[28] A. Iraji, A. Nouri, N. Edraki, S. Pirhadi, M. Khoshneviszadeh, and M. Khoshneviszadeh, "One-pot synthesis of thioxo-tetrahydropyrimidine derivatives as potent $\beta$-glucuronidase inhibitor, biological evaluation, molecular docking and molecular dynamics studies," Bioorganic \& Medicinal Chemistry, vol. 28, no. 7, Article ID 115359, 2020.

[29] B. Bano, K. M. Arshia, K. Khan et al., "Synthesis, in vitro $\beta$ -glucuronidase inhibitory potential and molecular docking studies of quinolines," European Journal of Medicinal Chemistry, vol. 139, pp. 849-864, 2017.

[30] M. Taha, N. H. Ismail, S. Imran et al., "Synthesis of novel benzohydrazone-oxadiazole hybrids as $\beta$-glucuronidase inhibitors and molecular modeling studies," Bioorganic \& Medicinal Chemistry, vol. 23, no. 23, pp. 7394-7404, 2015.

[31] K. M. Khan, F. Rahim, A. Wadood et al., "Evaluation of bisindole as potent $\beta$-glucuronidase inhibitors: synthesis and in silico based studies," Bioorganic \& Medicinal Chemistry Letters, vol. 24, no. 7, pp. 1825-1829, 2014.

[32] N. K. N. A. Zawawi, M. Taha, N. Ahmat et al., "Novel 2,5disubtituted-1,3,4-oxadiazoles with benzimidazole backbone: a new class of $\beta$-glucuronidase inhibitors and in silico studies," Bioorganic \& Medicinal Chemistry, vol. 23, no. 13, pp. 3119-3125, 2015.

[33] K. M. Khan, F. Rahim, S. A. Halim et al., "Synthesis of novel inhibitors of $\beta$-glucuronidase based on benzothiazole skeleton and study of their binding affinity by molecular docking," Bioorganic \& Medicinal Chemistry, vol. 19, no. 14, pp. 4286-4294, 2011. 